Journal of Maternal and Child Health (2019), 4(3): 170-179

https://doi.org/10.26911/thejmch.2019.04.03.04

\title{
Biopsychosocial Determinants of Early Marriage in Wonogiri District, Central Java: A Logistic Regression
}

\author{
Meylsa Rima Kamilda1), Ismi Dwi Astuti Nurhaeni²), Rita Benya Adriani') \\ 1)Masters Program in Public Health, Universitas Sebelas Maret \\ 2)Faculty of Social and Political Sciences, Universitas Sebelas Maret
}

\begin{abstract}
Background: Early marriage is one of the problems in Indonesia and the developing countries. It represents one of the violations of women's human right. Early marriage had physical, psychological, and social negative effects in the affected women. This study aimed to examine the determinants of early marriage in Wonogiri District, Central Java.

Subjects and Method: This was a case control study carried out in Wonogiri, Central Java, from October to November 2018. A sample of 200 women was selected by fixed disease sampling, consisting of 50 women with early marriage and 150 women with timely marriage. The dependent variable was early marriage. The independent variables were menarche age, unwanted pregnancy, education level, gender inequality, parental perception on early marriage, local culture, residence, and employment before marriage. The data were collected using questionnaires and analyzed by logistic regression.

Results: The risk of early marriage increased with age of menarche $<12$ years $(\mathrm{OR}=3.41 ; 95 \% \mathrm{CI}=$ 1.12 to $10.36 ; p=0.003)$, gender inequality $(\mathrm{OR}=4.70 ; 95 \% \mathrm{CI}=1.53$ to $14.40 ; \mathrm{p}=0.007)$, and local culture pro early marriage $(\mathrm{OR}=5.33 ; 95 \% \mathrm{CI}=1.62$ to $17.42 ; \mathrm{p}=0.006)$. The risk of early marriage decreased with wanted pregnancy $(\mathrm{OR}=0.17 ; 95 \% \mathrm{CI}=0.043$ to $0.70 ; \mathrm{p}=0.014)$, education level $(\mathrm{OR}=0.03 ; 95 \% \mathrm{CI}=0.01$ to $0.14 ; \mathrm{p}=0.001)$, positive parental perception $(\mathrm{OR}=0.24 ; 95 \% \mathrm{CI}=$ 0.08 to $0.77 ; \mathrm{p}=0.016)$, neighborhood in city $(\mathrm{OR}=0.29 ; 95 \% \mathrm{CI}=0.09$ to $0.93 ; \mathrm{p}=0.035)$, and work before marriage $(\mathrm{OR}=0.20 ; 95 \% \mathrm{CI}=0.63$ to $0.65 ; \mathrm{p}=0.007)$.

Conclusion: The risk of early marriage increases with age of menarche <12 years, gender inequality, and local culture pro early marriage. It decreases with wanted pregnancy, education level, positive parental perception, neighborhood in city, and work before marriage.
\end{abstract}

Keywords: early marriage, gender inequality, local culture

\section{Correspondence:}

Meylsa Rima Kamilda. Masters Program in Public Health, Universitas Sebelas Maret. Jl. Ir. Sutami 36 A, Surakarta, Central Java 57126, Indonesia. Email: meyl.rima@gmail.com.

Mobile: 6285728805820

\section{BACKGROUND}

Early marriage (age of marriage less than 18 years) is a health problem that is one of the MDG targets which is continued in the SDGs (UNICEF, 2018a; WHO, 2013; UNFPA, 2012). A total of 700 million women living in 2010 were married at the age of children with one-third of those married at the age of 15 years and it is estimated that 142 million women will marry before the age of 18 in the 2011-2020 period (UNICEF, 2014; UNICEF, 2016a; UNFPA,
2012). Furthermore, according to the United Nations Department of Economic and Social Affairs (UNDESA), the rate of early marriage in Indonesia ranks 37 out of 158 countries in the world, while in Southeast Asia Indonesia ranks second after Cambodia (UNDESA, 2011).

Central Java Province is a province with early marriage prevalence in the second highest district and sub-district after East Java, followed by South Kalimantan (UNICEF, 2016b). Meanwhile, 
Wonogiri Regency is one of the districts in Central Java that has high early marriage rates. Based on data from the Wonogiri Regency Religious Court, there were 30 cases of marriage dispensations in JanuaryAugust 2017. Meanwhile, the submission of the marriage dispensation early in 2015 was 49 cases and in 2016 it increased to 66 cases.

High rates of early marriage can occur due to several factors, one of them is biological factors in women. Early age of menarche will increase the risk of early marriage (Raj et al., 2015). In addition, early puberty causes psychosocial problems and health problems including increasing the risk of free sex and early marriage caused by unwanted pregnancies (Golub et al., 2008; Djamilah and Kartikawati, 2014). Early marriage is one form of gender inequality because it respects the survival, development, protection and participation of men versus women (UNICEF, 2010). Gender inequality and the views of the community and family towards women are factors that contribute to the high prevalence of early marriage (BPS, 2016). In addition, another factor that causes early marriage is rural living and poverty. Teenage pregnancies and becoming mothers in adolescence have a greater risk 1.5 times in rural areas compared to urban areas (UNFPA, 2014; UNICEF, 2016). Early marriage will increase a variety of health risks in adolescents (anemia, preeclampsia, malnutrition, increase mortality) if they are pregnant and give birth (WHO, 2013; Gibbs et al., 2012). Furthermore, pregnancy at an early age is also a public health problem and has an impact on the social environment such as social isolation, disrupting schools, limiting opportunities to get desired careers, and the risk of domestic violence both physical violence and sexual violence. (Patton et. Al., 2009; Speizer and
Pearson, 2011; Mouli et al., 2013; UNICEF, 2017). In addition, marriage before the age of 18 will increase depression and suicidal ideation in women (Gage, 2012).

Based on the explanation above, it can be concluded that early marriage is a complex problem, so it is important to make efforts to reduce the rate of early marriage. This study aims to determine the most influential bio-psychosocial determinants of early marriage using logistic regression. The biological factors studied included the age of menarche and pregnancy was not alleviated. Meanwhile, the psychosocial factors studied included the level of education, gender inequality, people's perceptions of girls, local culture, areas of residence and employment before marriage.

\section{SUBJECTS AND METHOD \\ 1. Study Design \\ This was a case control study conducted at Ngadirojo, Sidoharjo, Jatisrono, Jatiroto, Jatipurno, Slogohimo, Bulukerto, and Kismantoro Subdistricts, in October to November 2018. A sample of 200 women was selected for this study by fixed disease sampling.}

\section{Population and Samples}

The target population of this study was all women who were married in 2017. The population of the case in this study was mothers who were married at the age of less than 18 years in KUA in Wonogiri Regency amounting to 50 people, while the population for control groups was mothers who first married at the age more than 18 years in KUA in Wonogiri Regency with 150 subjects. The sampling was done using fixed disease sampling.

\section{Study Variables}

The dependent variable is early marriage. Meanwhile, the independent variables are menarche age, unwanted pregnancy, educa- 
tion level, gender inequality, parental perceptions of girls, local culture, place of residence, and employment before marriage.

\section{Operational definition of variables}

Early marriage was defined as the first marriage performed by women before the age of 18. The data were collected from District Religion Office. The measurement scale was categorical coded o for timely married and 1 for early marriage.

Age of menarche was defined as the age of a teenage girl first menstruation as a sign that the reproductive organs have begun to function. The measurement scale was continous and transformed into dichotomous, coded $\mathrm{o}$ for $\geq 12$ years old and 1 for $<12$ years old.

Unwanted pregnancy was defined as a pregnancy that occurs in unmarried teenagers. The measurement scale was categorical, coded $o$ for yes and 1 for no.

Education was defined as the highest level of education attained by women of reproductive age. The measurement scale was categorical and transformed into dichotomous, coded o for <senior high school and 1 for $\geq$ senior high school.

Gender inequality was defined as the difference in perceptions, treatment, and giving rights to male and female gender in life so that it affects the early marriage. The measurement scale was continous and transformed into dichotomous, coded o for good (score $<19$ ) and 1 for poor (score $\geq 19$ ).

Parental perception was defined as parental way of interpreting girls related to early marriage. The measurement scale was continous and transformed into dichotomous, coded o for negative (score $\geq 14$ ) and 1 for positive (score $<14$ ).

Local culture was defined as all forms of thought, willingness, feeling, and work that are promoted in upholding social order in the community so that it influences the behavior, views and beliefs of the local community towards early marriage. The measurement scale was continous and transformed into dichotomous, coded o for did not supportive (score <19) and 1 for supportive (score $\geq 19$ ).

The living environment was defined as where women live before marriage which is influenced by the background of the community, social interaction between citizens, public facilities, and social status that affects early marriage. The measurement scale was continous and transformed into dichotomous, coded o for urban $(\geq 23)$ and 1 for city $(<23)$.

Working/occupation was related to an effort made by women before marriage to earn income. The measurement scale was categorical coded o for not working and 1 for employed.

\section{Study Instrument}

The study instrument used for data collection was a questionnaire. Data collection was carried out using reliability tested questionnaire. The reliability test was conducted using Alpha Cronbach test to 20 study subjects with total item correlations $(>0.20)$ and Cronbach alpha $(\geq 0.70)$.

\section{Data Analysis}

Sample characteristics were described by univariate analysis. Bivariate analysis used Chi square. Multivariate analysis used a multiple logistic regression.

\section{Research Ethics}

The research ethics include informed consent, anonymity, confidentiality and ethical clearance. The ethical clearance in this study was conducted at Faculty of Medicine, Universitas Sebelas Maret, Surakarta, Central Java, with the number: 308 / UN27.6 / KEPK / 2018.

\section{RESULTS}

\section{Univariate Analysis}

Table 1 showed that the study subjects who unemployed before marriage were 80 
women (40\%) and those who employed were 120 women (60\%). Women who experienced menarche $\geq 12$ years were 131 (65.5\%).

Table 1. Sample characteristics

\begin{tabular}{|c|c|c|}
\hline Characteristics & $\mathbf{n}$ & $\%$ \\
\hline \multicolumn{3}{|l|}{ Age } \\
\hline$<21$ years old & 97 & 48.50 \\
\hline$\geq 21$ years old & 103 & 51.50 \\
\hline \multicolumn{3}{|l|}{ Income } \\
\hline$<\operatorname{Rp} 1,524,000$ & 120 & 60 \\
\hline$\geq \operatorname{Rp} 1,524,000$ & 80 & 40 \\
\hline \multicolumn{3}{|l|}{ Occupation } \\
\hline Not working & 80 & 40 \\
\hline Working & 120 & 60 \\
\hline \multicolumn{3}{|l|}{ Education } \\
\hline Low & 95 & 47.50 \\
\hline High & 105 & 52.50 \\
\hline \multicolumn{3}{|l|}{ Age at menarche } \\
\hline$<12$ years old & 69 & 34.50 \\
\hline$\geq 12$ years old & 131 & $65 \cdot 50$ \\
\hline \multicolumn{3}{|l|}{$\begin{array}{l}\text { Unwanted } \\
\text { pregnancy }\end{array}$} \\
\hline Yes & 34 & 17 \\
\hline No & 166 & 83 \\
\hline \multicolumn{3}{|l|}{ Gender Inequality } \\
\hline Yes & 81 & 40.50 \\
\hline No & 119 & 59.50 \\
\hline \multicolumn{3}{|l|}{ Parental perception } \\
\hline Poor & 101 & 50.50 \\
\hline Good & 99 & 49.50 \\
\hline \multicolumn{3}{|l|}{ Local Culture } \\
\hline $\begin{array}{l}\text { Supporting early } \\
\text { marriage }\end{array}$ & 59 & 29.50 \\
\hline $\begin{array}{l}\text { Not supporting early } \\
\text { marriage }\end{array}$ & 141 & 70.50 \\
\hline \multicolumn{3}{|l|}{ Area of Residence } \\
\hline Village & 98 & 49 \\
\hline City & 102 & 51 \\
\hline
\end{tabular}

As many as 103 women (51.5\%) were at age $\geq 21$ years old. As many as 120 women (60\%) had family income $<\mathrm{Rp} 1,524,000$. Women with high education level were 105 (52.5\%). Women with unwanted pregnancy were 34 (17\%). Women who experienced gender inequality were 81 (40.5\%). As many as 101 women (50.5\%) received negative perception from their parents.
Women exposed to local cultures support early marriage were 59 (29.5\%) and women who were not exposed to local culture in early marriage as many as 141 (70.5\%). As many as 102 women (51\%) living in the city.

\section{Bivariate Analysis}

Table 2 showed the results of bivariate analysis. Table 2 showed that early marriage was increased by menarche age $<12$ years old $(\mathrm{r}=3.38 ; \mathrm{p}<0.001)$, gender inequality $(\mathrm{p}<0.001 ; \mathrm{r}=7.89)$, and local culture $(\mathrm{p}<0.001 ; \mathrm{r}=4.89)$.

Early marriage was decreased by wanted pregnancy $(\mathrm{r}=0.21 ; \mathrm{p}<0.001)$, high educational level $(r=0.02 ; p<0.001)$, good parental perception $(\mathrm{r}=0.23 ; \mathrm{p}<0.001)$, living in the city $(\mathrm{r}=0.21 ; \mathrm{p}<0.001)$, and employed $(\mathrm{r}=0.27 ; \mathrm{p}<0.001)$.

\section{Multivariate Analysis}

Table 3 showed the results of multiple logistic regression analysis. Table 3 showed that age at menarche, unwanted pregnancy, education, gender inequality, parental perception, local culture, neighborhood, and employment were related to early marriage.

Age at menarche had a positive effect on early marriage. Female adolescents who experienced early menarche would have a higher risk of having an early marriage $(\mathrm{OR}=1.23 ; 95 \% \mathrm{CI}=1.12$ to $10.36 ; \mathrm{p}=$ $0.020)$.

Unwanted pregnancy had an effect on early marriage. Female adolescents who wanted pregnancy would have a lower risk of early marriage $(\mathrm{OR}=0.17 ; 95 \% \mathrm{CI}=0.04$ to $0.70 ; p=0.014$ ).

Educational level has a negative effect on early marriage. Highly-educated women have lower risk of early marriage ( $\mathrm{OR}=$ 0.03; 95\% $\mathrm{CI}=0.01$ to 0.14 ; $\mathrm{p}<0.001)$.

Gender inequality had a positive effect on early marriage. Women who experienced gender inequality had greater risk to 
experience early marriage $(\mathrm{OR}=4.70 ; 95 \%$ $\mathrm{CI}=1.52$ to $14.40 ; \mathrm{p}=0.007)$.

Parental perception on daughters has a positive effect on early marriage. Women who got good perception from parents have lower risk of early marriage $(\mathrm{OR}=0.24$; 95\% $\mathrm{CI}=0.08$ to $0.77 ; \mathrm{p}=0.016$ ).

Local culture has a positive effect on early marriage. Women who were exposed to local culture which supported early marriage were more likely to have early marriage $(\mathrm{OR}=5.33 ; 95 \% \mathrm{CI}=1.63$ to 17.42 ; $\mathrm{p}=0.006)$.

Neighborhood has a negative effect on early marriage. Women who lived in the city have lower risk to experience early marriage $(\mathrm{OR}=0.29 ; 95 \% \mathrm{CI}=0.09$ to 0.92 ; $\mathrm{p}=0.035$ ). Employment had a negative effect on early marriage. Women who worked before married have lower risk to experience early marriage $(\mathrm{OR}=0.20 ; 95 \%$ $\mathrm{CI}=0.06$ to $0.65 ; \mathrm{p}=0.007$ )

Table 2. The result of bivariate analysis

\begin{tabular}{|c|c|c|c|c|c|c|c|c|}
\hline \multirow{2}{*}{$\begin{array}{l}\text { Independent } \\
\text { Variables }\end{array}$} & \multicolumn{2}{|c|}{$\begin{array}{c}\text { Early } \\
\text { Marriage }\end{array}$} & \multicolumn{2}{|c|}{$\begin{array}{l}\text { Non-Early } \\
\text { Marriage }\end{array}$} & \multirow{2}{*}{ OR } & \multicolumn{2}{|c|}{ CI 95\% } & \multirow[b]{2}{*}{$\mathbf{p}$} \\
\hline & $\mathbf{n}$ & $\%$ & $\mathbf{n}$ & $\%$ & & $\begin{array}{l}\text { Lower } \\
\text { limit }\end{array}$ & $\begin{array}{l}\text { Upper } \\
\text { Limit }\end{array}$ & \\
\hline \multicolumn{9}{|l|}{ Educational Level } \\
\hline Low Education & 48 & 96 & 47 & 31.3 & 0.02 & 0.01 & 0.82 & $<0.001$ \\
\hline High Education & 2 & 4 & 103 & 68.7 & & & & \\
\hline Menarche Age & & & & & & & & \\
\hline Early Menarche & 28 & 56 & 41 & 23.3 & 3.38 & 1.74 & 6.57 & $<0.001$ \\
\hline Timely Menarche & 22 & 44 & 109 & 72.7 & & & & \\
\hline \multicolumn{9}{|l|}{ Unwanted } \\
\hline $\begin{array}{l}\text { Pregnancy } \\
\text { Yes }\end{array}$ & 18 & 36 & 16 & 10.7 & 0.21 & 0.10 & 0.46 & $<0.001$ \\
\hline No & 32 & 64 & 134 & 89.3 & & & & \\
\hline \multicolumn{9}{|l|}{ Gender Inequality } \\
\hline Yes & 38 & 76 & 43 & 28.7 & 7.89 & $3 \cdot 76$ & 16.5 & $<0.001$ \\
\hline No & 12 & 24 & 107 & 71.3 & & & & \\
\hline \multicolumn{9}{|l|}{ Parental } \\
\hline $\begin{array}{l}\text { Perception } \\
\text { Bad Perception }\end{array}$ & 38 & 76 & 63 & 42 & 0.23 & 0.11 & 0.47 & $<0.001$ \\
\hline \multicolumn{9}{|l|}{ Local Culture } \\
\hline $\begin{array}{l}\text { Supporting Early } \\
\text { Marriage }\end{array}$ & 28 & 56 & 31 & 20.7 & 4.89 & 2.47 & 9.68 & $<0.001$ \\
\hline $\begin{array}{l}\text { Not Supporting Early } \\
\text { Marriage }\end{array}$ & 22 & 44 & 119 & 79.3 & & & & \\
\hline \multicolumn{9}{|l|}{ Neighborhood } \\
\hline Village & 38 & 76 & 60 & 40 & 0.21 & 0.10 & 0.44 & $<0.001$ \\
\hline City & 12 & 24 & 90 & 60 & & & & \\
\hline \multicolumn{9}{|l|}{ Employment } \\
\hline Unemployed & 32 & 64 & 48 & 32 & 0.27 & 0.14 & 0.52 & $<0.001$ \\
\hline Employed & 18 & 36 & 102 & 68 & & & & \\
\hline
\end{tabular}


Table 3. Logistic Regression Analysis

\begin{tabular}{|c|c|c|c|c|}
\hline \multirow{2}{*}{ Independent Variables } & \multirow{2}{*}{$\mathbf{O R}$} & \multicolumn{2}{|c|}{ CI 95\% } & \multirow[b]{2}{*}{$\mathbf{p}$} \\
\hline & & Lower limit & Upper limit & \\
\hline Menarche age $(<12$ years old $)$ & 3.41 & 1.12 & 10.36 & 0.030 \\
\hline Wanted pregnancy & 0.17 & 0.04 & 0.70 & 0.014 \\
\hline $\begin{array}{l}\text { Current education ( } \geq \text { senior high } \\
\text { school) }\end{array}$ & 0.03 & 0.01 & 0.14 & $<0.001$ \\
\hline Gender inequality & 4.70 & 1.53 & 14.40 & 0.007 \\
\hline Parental perception (positive) & 0.24 & 0.08 & 0.77 & 0.016 \\
\hline $\begin{array}{l}\text { Local culture (pro early } \\
\text { marriage) }\end{array}$ & $5 \cdot 33$ & 1.63 & $17 \cdot 42$ & 0.006 \\
\hline Neighborhood (city) & 0.29 & 0.09 & 0.92 & 0.035 \\
\hline Employment & 0.20 & 0.06 & 0.65 & 0.007 \\
\hline Log likelihood: -44.85 & & & & \\
\hline Negelkerke R Square: 60.12\% & & & & \\
\hline
\end{tabular}

\section{DISCUSSIONS \\ 1. The effect of menarche age on early marriage}

The results of this study showed that there was a positive effect of the age of menarche on early marriage. Women who experienced early menarche ( $<12$ years) would have a higher risk of having an early marriage $(b=1.23 ; 95 \% \mathrm{CI}=1.12$ to 10.36 ; $\mathrm{p}=0.020$ ). The result of this study was in line with the study by Raj et al. (2015), which showed that the earlier the age of menarche, the higher the risk for early marriage. The risk of early marriage would be even greater if it was followed by low education.

Tey et al. (2018) stated that adolescents with menarche age less than 12 years were 4.4 times more likely to start sexual activity earlier than adolescents with the menarche age of 14 years. In addition, earlier menarche increased the risk of risky sexual behavior, pregnancy and labor before marriage. If it was not followed by good reproductive health information, menarche, pregnancy, and labor would occur in the same year.

\section{The effect of unwanted pregnancy on early marriage}

The results of this study showed that there was a negative effect of unwanted pregnancy on early marriage. Adolescents who did not experience unwanted pregnancy would have a lower risk of early marriage $(b=-$ $1.76 ; 95 \% \mathrm{CI}=0.04$ to $0.70 ; \mathrm{p}=0.014)$.

This study was in line with a study by Husna et al. (2016) which found that unwanted pregnancies would increased the risk of early marriage by 3.4 times greater. Unwanted pregnancies would cause adolescents to feel embarrassed, quit school, and affected their psychological conditions. Therefore, parents or the community would ask them to get married to resolve unwanted pregnancy problems. This was done to cover up the family's shame and pressure from the environment (Husna et al., 2016; Fitriani et al., 2015).

\section{The effect of educational level on early marriage}

The results of this study showed that there was a negative effect of educational level on early marriage. Women with high level of education had a lower risk of early marriage $(b=-3.63 ; 95 \% \mathrm{CI}=0.01$ to $0.14 ; \mathrm{p}<0.001)$.

This study was in line with a study by Field and Ambrus (2008), which showed 
that one of the effects of increasing levels of education was increasing the average age of marriage in adolescents. Another study that was in line with this research was a study done by Raymo (2015) which found that women who were economically independent were women with higher education who tend to not choose to have early marriage.

Female adolescents who have a high level of education would reduce the risk of early marriage. This was because women with high levels of education have the desire to have careers and get the desired job rather than getting married at a young age (Kamal, 2012; Kamal et al., 2015).

\section{The effect of gender inequality on early marriage}

The results of this study showed that there was a positive effect of gender inequality on early marriage. Women who experienced gender inequality have greater risk to have early marriage $(b=1.55 ; 95 \% \mathrm{CI}=1.52$ to 14.40; $\mathrm{p}=0.007$ ).

This study was in line with a study by Carmichael (2011), which stated that gender inequality was one of the main causes of early marriage. Families and communities see female adolescents as having no other role than to be wives, whereas in male adolescent, they would be seen as those who would take care of their parents and wife. On the other hand, women were considered to increase the economic burden in the family if they postponed their marriages. In some poor and developing countries, women were considered to have lower status in society than men.

\section{The effect of parental perception on early marriage}

The results of this study showed that there was a negative effect of parents' perception on daughters on early marriage. Women who got positive perception from parents have a lower risk of early marriage $(b=1.42$; 95\% $\mathrm{CI}=0.08$ to $0.77 ; \mathrm{p}=0.016$ ).

According to Montazeri (2016), parents were the main factors that encourage young women to get married early. Marrying a child at a young age was one of the ways to maintain children's safety and protect their children from promiscuity and unwanted pregnancy (Lee-Rife et al., 2015; Bhanji and Punjani, 2014). Parents argued that marrying their children at a young age was one of the ways for children to become mature and responsible (Bhanji dan Punjani, 2014).

\section{The effect of local culture on early marriage}

The results of this study showed that there was a positive effect of local culture on early marriage. Women who were exposed to local culture which supported early marriage were more likely to have early marriage $(b=1.68 ; 95 \% \mathrm{CI}=1.63$ to $17.42 ; \mathrm{p}=0.006)$. This study was in line with a study done by Karjono (2017) which stated that local influence could increase the risk of early marriage $(\mathrm{OR}=3.41 ; 95 \% \mathrm{CI}=1.87$ to 3.27 ; $\mathrm{p}=\mathrm{p}=0.007)$.

A study by Husna et al. (2016) showed that there was a positive, direct, and significant relationship between local culture and early marriage. Early marriage that occurred in Sleman, Yogyakarta was a type of mixed marriage, which was marriage that occurred due to the decisions of the parents, but the adolescents have a right to choose their partners. In addition, most parents in Sleman, Yogyakarta chose to marry their children at a young age to prevent the occurrence of extramarital sex and extramarital pregnancy so that the good name of the family was protected.

\section{The effect of neighborhood on early marriage}

The results of this study showed that there was a negative effect of neighborhood on 
early marriage. Women who lived in the city have lower risk to experience early marriage $(b=-1.23 ; 95 \% \mathrm{CI}=0.09$ to 0.92 ; $\mathrm{p}=$ 0.035).

Rahman (2016) showed that important factor that contributed to early marriage was the neighborhood. Women who lived in rural environments have higher risk for early marriage compared to women who lived in urban environments. Women in rural environments have low levels of education, socio-economic conditions, and were more difficult to access mass media related to the various effects of early marriage so this increased the risk of early marriage.

On the other hand, a study of Guo et al. (2012), showed that adolescents who lived in urban areas have a risk of early sexual activity and the risk of extramarital sexual behavior was greater than adolescents who lived in rural areas. This happened because of social changes that occurred more rapidly in urban areas. Meanwhile, for rural areas, extramarital sexual behavior was taboo. Therefore, to avoid sexual behavior outside of marriage, parents chose to ask their daughter to get married.

\section{The effect of employment on early marriage}

The results of this study showed that there was a negative effect of employment on early marriage. Women who worked before married have lower risk to experience early marriage $(b=-1.60 ; 95 \% \mathrm{CI}=0.06$ to 0.65 ; $\mathrm{p}=0.007$ ).

This study was in line with a study by Kamal et al. (2015) which stated that women who did not work and did not have enough ability were at greater risk of experiencing early marriage. This was in line with a study of Pohan (2017) which stated that young women who did not work would have a risk of getting married early by 4.21 times greater than young women who have a job. Female adolescents who did not stay at home and did not have job would be bored. Therefore, there was a desire to get married because they thought that it was better to get married than to become unemployed and became a burden to the family.

This study concluded that there was a relationship between age of menarche, unwanted pregnancy, level of education, gender inequality, parents perceptions of daughters, local culture, neighborhood, and employment with the occurrence of early marriage in Wonogiri District. Early age of menarche, experiencing unwanted pregnancy, low education, gender inequality, poor perception of daughters, the existence of a local culture that supported early marriage, the village environment, and not working before marriage would increase the risk of early marriage.

\begin{tabular}{l}
\hline REFERENCES \\
\hline Bhanji SM, Punjani NS (2014). Determi- \\
nant of child (early) marriage among \\
young girls - a public health issues. \\
Journal of Women,s Health Care. \\
3(3): 1. doi: http://dx.doi.org/10.41- \\
72/2167-o420.10oo161 \\
BPS (Badan Pusat Statistik) (2016). Kema- \\
juan yang tertunda: analisis data \\
perkawinan usia anak di Indonesia. \\
https://www.unicef.org/indonesia/id \\
/Laporan_Perkawinan_Usia_Anak.p \\
df - Diakses Maret 2018 \\
Carmichael S (2011). Marriage and power: \\
age at first marriage ang spousal age \\
gap in Lesser Developed Countries. \\
History of the Family. 16: 431-3. doi: \\
https://doi.org/10.1016/j.hisfam.2011 \\
.o8.oo2 \\
Djamilah, Kartikawati R (2016). Dampak \\
Perkawinan Anak di Indonesia. \\
Jurnal Studi Pemuda. 3(2): 9.
\end{tabular}


Field e, Ambrus A (2008). Early marriage, age of menarche, and female schooling attaintment in Bangladesh. Journal of Political Economy, 116(5): 881. doi: https://doi.org/10.1086/593333

Fitriani D, Nugraha GI, Husin F, Mose JC, Sunjaya DK, Sukandar H (2015). Kajian kualitatif faktor-faktor yang memengaruhi pernikahan remaja perempuan. IJEMC, 2(3): 42.

Gage AJ (2012). Association of Child marriage with suicidal thoughts and attempts among adolescent girls in Ethiopia. Journal of Adolescent Health 52: 656. doi: https://doi.org/10.1016/j.jadohealth.2012.12.007

Gibbs CM, Wendt A, Peters S, Hogue CJ (2012). The impact of early marriage at first childbirth on matermal and infant health. Paediatric and Perinatal Epidemiology. 26(1): 262-4. doi: https://doi.org/10.1111/j.1365-3016.2012.01290.x.

Golub MS, Collman GW, Foster PMD, Kimmel CA, Meyts ERD, Reiter EO, Sharpe RM, et al (2008). Public health implications of altered puberty timing. Pediatrics. 121(3): 5266. doi: 10.1542/peds.2007-1813G.

Guo W, Wu Z, Qiu Y, Chen G, Zheng X. (2012). The Timing of sexual debut among Chinese Youth. Internatioal Perspective on Sexual and Reproductive Health. 30(4): 202.

Husna N, Demartoto A, Resati SH (2016). Factor associated with early mariage in Sleman, Yogyakarta. Journal of Health Promotion and Behavior. 1(2): 96-7. doi: https://doi.org/10.26911/thejhpb.2016.01.02.04.

Karjono, Bakta IM, Karmaya INM, Pradnyaparamita D, Murtianingsih. (2017). Force, Support, and Endorsing Factors of Early Marriage in Adolescent Sasak (Sasak Ethnic) in
Central Lombok. International Researh Journal of Engineering, IT,\& Scientific Research. 3(2): 146-52.

Kamal SMM, Hassan CH, Alam GM, Ying Y (2015). Child Marriage in Bangladesh: Trends and Determinants. Journal of Biosocial Science, 47: 135. doi: https://doi.org/10.1017/So021932013000746.

Kamal SMM (2012). Decline in child marriage and changes in its effect on reproductive outcomes in Bangladesh. Journal of Health Population and Nutrition. 30(3): 327.

Lee-Rife S, Malhotra A, Warner A, Glinski AM (2012). What works to prevent child marriage: A Review of the evidence. studies in family planning. 43(4): 286. doi: https://doi.org/10.1111/j.1728-4465.2012.00327.x.

Montazeri S, Gharacheh M, Mohammadi N, Rad JA, Ardabili HE (2016). Determinant of Early Marriage from Married Girls' Perpectives in Iranian Setting: A Qualitattive Study. Journal of Environmental and Public Health. doi: http://dx.doi.org/10.1155/2016/8615929.

Mouli VC, Camacho AV, Michaud PA (2013). WHO guidelines on preventing early pregnancy and poor reproductive outcomes among adolescents in developing country. Journal of Adolescent Health, 52: 517-22. doi: https://doi.org/10.1016/j.jadohealth. 2013.03.002

Patton GC, Coffey C, Sawyer SM,Viner RM, Haller DM, Bose K, Vos T, et al. (2009). Global patterns of mortality in young people. A systematic analysis of population data. Lancet. 374: 88192. doi: https://doi.org/10.1016/So140-6736(09)60741-8.

Pohan NH (2017). Faktor yang berhubungan dengan pernikahan usia dini ter- 
hadap remaja putri. Jurnal Endurance 2(3): 430. http://issn.pdii.lipi.go.id/issn.cgi?daftar\&1450147330\&1 $\& \& 2015$.

Rahman M (2018). Determinantes of early marriage in Bangladesh: A evidence of the nationally representative survey. International Journal of Sociology and Anthropology, 9(1): 5-6. doi: 10.5897/IJSA2016.0684

Raj A, Ghule M, Nair S, Saggurti N, Balaiah D, Silverman JG (2015). Age at menarche, education, and child marriage among young wives in rural Maharashtra, India. International Journal of Gynecology and Obstetrics. doi: https://doi.org/10.1016/j.ijgo.2015.04.044.

Speizer IS, Pearson E (2011). Association between early marriage and intimate partner violence in India: A focus on youth from Bihar and Rajasthan. Journal of Interpersonal Violence. 26(10): 1963-1981.

Tey NP, Lai SL, Tho ST (2018). Age at menarche and sexual debut among young Filipino Women. Journal of Biosocial Science, 1-18. doi: 10.1017/So021932017000682.

UNDESA (United Nation Departement of Economic and Social Affairs). 2011. Population Facts: World Marriage Pattern. http://www.un.org/en/development/desa/population/publications/pdf/popfacts/PopFacts_20111.pdf.

UNFPA (United Nation Population Fund). 2014. UNFPA Indonesia Monograph Series: No. 2 Youth in Indonesia. https://indonesia.unfpa.org/sites/def ault/files/pub-pdf/BUKU_Monograph_No2_Youth_in_Indonesia_E NG_05_Low-res.pdf - Diakses Maret 2018.
(2012). Marrying Too Young: End Child Marriage. UNFPA. https://www.unfpa.org/sites/default/files/pub-pdf/MarryingTooYoung.pdf - Diakses Maret 2018.

UNICEF (United Nations Children's Fund). (2018a). Child Protection. http://data.unicef.org/topic/child-protection/child-marriage/. Diakses Maret 2018.

(2017). Child marriage is a violation of human rights but is all too common. https://data.unicef.org/topic/child-protection/child-marriage/ Diakses 21 Januari 2018

(2016a). Child Marriage in Indonesia: Progress on Pause. https://www.unicef.org/indonesia/UNICEF_ Indonesia_Child_Marriage_Reserach _Brief_pdf - Diakses Maret 2018, hlm: 1-5

(2016b). Policy brief child marriage in Indonesia: Past Progress at a standstill. https://www.unicef.org/indonesia/Child_Marriage_Report_P olicy_Brief_(Report_Summary)_160 316.pdf - Diakses Maret 2018.

(2014). Ending child marriage: progress and prospects. https://data.unicef.org/wp-content/uploads/2015/12/Child-Marriage-Brochure-HR_164.pdf - Diakses Maret 2018.

(2010). Progress for children achieving the MDGs with equity. https://www.unicef.org/publications/ files/Progress_for_Children-No.9_EN_o81710.pdf. Diakses April 2018.

WHO (World Health Organizarion). 2013. Child Marriage: 39.000 every day. http://www.who.int/mediacentre/ne ws/releases/2013/child_marriage_20 130307/en/. Diakses 20 Januari 2018 